\title{
Absence of RKIP expression is an independent prognostic biomarker for gastric cancer patients
}

\author{
OLGA MARTINHO $^{1,2}$, KLEBER SIMÕES $^{3}$, ADHEMAR LONGATTO-FILHO $^{1,2,4,5}$, \\ CARLOS EDUARDO JACOB ${ }^{6}$, BRUNO ZILBERSTEIN ${ }^{6}$, CLÁUDIO BRESCIANI $^{6}$, \\ JOAQUIM GAMA-RODRIGUES ${ }^{6}$, IVAN CECCONELLO ${ }^{6}$, VENÂNCIO ALVES $^{3,5}$ and RUI MANUEL REIS ${ }^{1,2,4}$ \\ ${ }^{1}$ Life and Health Sciences Research Institute (ICVS), Health Sciences School, University of Minho, Braga; \\ ${ }^{2}$ ICVS/3B's - PT Government Associate Laboratory, Braga/Guimarães, Portugal; ${ }^{3}$ Department of Pathology, \\ University of São Paulo School of Medicine; ${ }^{4}$ Molecular Oncology Research Center, Barretos Cancer Hospital, \\ Barretos; ${ }^{5}$ Laboratory of Medical Investigation (LIM) 14, Faculty of Medicine, São Paulo State University; \\ ${ }^{6}$ Department of Gastroenterology, Faculty of Medicine, University of São Paulo, São Paulo, Brazil
}

Received August 12, 2012; Accepted October 22, 2012

DOI: 10.3892/or.2012.2179

\begin{abstract}
Gastric cancer is a leading cause of cancer-related mortality, and the presence of lymph node metastasis an important prognostic factor. Downregulation of RKIP has been associated with tumor progression and metastasis in several types of neoplasms, being currently categorized as a metastasis suppressor gene. Our aim was to determine the expression levels of RKIP in gastric tissues and to evaluate its impact in the clinical outcome of gastric carcinoma patients. RKIP expression levels were studied by immunohistochemistry in a series of gastric tissues. Overall, we analysed 222 non-neoplastic gastric tissues, 152 primary tumors and 42 lymph node metastasis samples. We observed that RKIP was highly expressed in $\sim 83 \%$ of non-neoplastic tissues (including normal tissue and metaplasia), was lost in $\sim 56 \%$ of primary tumors and in $\sim 90 \%$ of lymph node metastasis samples. Loss of RKIP expression was significantly associated with several markers of poor clinical outcome, including the presence of lymph node metastasis. Furthermore, the absence of RKIP protein constitutes an independent prognostic marker for these patients. In conclusion, RKIP expression is significantly lost during gastric carcinoma progression being almost absent in lymph node metastasis samples. Of note, we showed that the absence of RKIP expression is associated with poor outcome features of gastric cancer patients, this being also an independent prognostic marker.
\end{abstract}

Correspondence to: Dr Rui Manuel Reis, Molecular Oncology Research Center, Barretos Cancer Hospital, Rua Antenor Duarte Villela, 1331, CEP 14784400 Barretos, S. Paulo, Brazil

E-mail: ruireis.hcb@gmail.com

Key words: RKIP, gastric carcinomas, prognosis

\section{Introduction}

The incidence and mortality of gastric cancer have declined steadily over the past several decades. Nonetheless, gastric cancer remains a major public health issue being the fourth most common cancer and the second leading cause of cancer death worldwide (1). Gastric neoplasia is largely composed of adenocarcinomas, accounting for over 95\% of cases (2). Pathologically, gastric adenorcarcinomas are most widely classified using Lauren and the World Health Organisation (WHO) classification system. In the Lauren classification, gastric cancers are stratified into intestinal, diffuse, and mixed types, whereas the WHO classification categorizes cancers according to features of histopathological differentiation, namely papillary, tubular, mucinous, and signet ring cell types (3). Genetically, gastric cancer is generally considered to result from accumulation of genetic alterations involving a variety of oncogenes and tumor suppressor genes, however, concrete genetic sequences in the development of gastric cancer still remain to be clarified $(3,4)$.

Raf kinase inhibitor protein (RKIP; also known as PEBP, for phosphatidylethanolamine-binding protein) is a widely expressed and highly conserved protein (5-7), which was firstly identified as a MAP kinase pathway inhibitor by modulating the function of Raf-1 $(8,9)$. Currently, is known that RKIP also suppresses the activation of the nuclear factor $\kappa \mathrm{B}(\mathrm{NF}-\mathrm{\kappa B})(10)$ and the regulator of G-protein coupled receptors (GRK-2) (11), and may be involved in regulation of the cell cycle (12). Thus, RKIP mediates important cellular mechanisms, including cell differentiation, cell cycle, apoptosis and cell migration, and is deregulated in several human disorders (13).

In cancer, RKIP is considered to be a signal transduction modulator and a metastasis suppressor (14), and downregulated in several human tumors, mainly in highly metastatic carcinomas (15-27). Noteworthy, RKIP has been shown to be a prognostic marker in prostate cancer, colorectal carcinomas, gliomas and GISTs (25,27-30).

Concerning RKIP expression in gastric carcinomas, there are three, yet contradictory studies (31-33). Thus, in the present 
Table I. Frequency of RKIP expression in gastric tissues.

\begin{tabular}{|c|c|c|c|c|c|}
\hline \multirow[b]{2}{*}{ Gastric tissues } & \multirow[b]{2}{*}{$\mathrm{N}$} & \multicolumn{2}{|c|}{ RKIP Expression } & \multirow[b]{2}{*}{ p (vs. Normal) } & \multirow[b]{2}{*}{$\mathrm{p}$ (vs. Primary tumor) } \\
\hline & & Positive (\%) & Negative $(\%)$ & & \\
\hline Normal & 163 & $138(84.7)$ & $25(15.3)$ & - & $<0.001$ \\
\hline Metaplasia & 59 & 47 (79.7) & $12(20.3)$ & 0.377 & $<0.001$ \\
\hline Primary tumor & 152 & $67(44.1)$ & $85(55.9)$ & $<0.001$ & - \\
\hline Lymph node metastasis & 42 & $4(9.5)$ & $38(90.5)$ & $<0.001$ & $<0.001$ \\
\hline
\end{tabular}

p, pearson value from $\chi^{2}$ test; vs., versus.

work, using a large and clinically well-characterized series of gastric carcinomas, we aimed first to evaluate the frequency of RKIP expression not only in tumor but also in normal and metastatic gastric tissues. Secondly, we aimed to determine whether RKIP expression could be used to predict clinical outcome of patients with gastric carcinomas.

\section{Materials and methods}

Patients and tissue samples. For the present study, the cases were retrospectively selected from the University of São Paulo Gastric Cancer Database: 152 patients with gastric adenocarcinoma operated at the Stomach and Small Bowel Unit Hospital das Clinicas, University of São Paulo, School of Medicine, São Paulo, Brazil, between February 1993 and December 2002. In total 416 different gastric tissues were analysed, including 163 normal mucosa, 59 metaplastic mucosa, 152 primary tumors and 42 lymph node metastasis samples. The samples were retrieved from the files of the Department of Pathology, and organized in tissue microarrays (TMAs). To achieve representative sampling and minimize sample loss, each case was included in duplicate in the TMAs. Additionally, formalin-fixed and paraffin-embedded prostate carcinoma and GISTs samples were used as positive and negative controls for immunohistochemistry, as previously described (27).

Relevant patient clinical data available included patients age, gender, tumor size and location, WHO classification, Lauren's classification, TNM staging, depth of invasion, lymph node metastases and lymphatic, vascular and neural invasions, desmoplasia, inflammatory infiltrated and follow-up, as previously described (34). The inclusion criteria were: patients with primary gastric adenocarcinoma submitted to subtotal or total gastrectomy with D2 lymphadenectomy, submucosa layer invasion or deeper (T1b or higher), at least 25 lymph nodes retrieved per case, absence of distant metastasis (M0), and available follow-up data. All patients were treated according to a well-established surgical protocol following the Japanese Gastric Cancer Association rules.

The histological sections, obtained from original paraffin blocks and, after hematoxylin and eosin staining, were submitted to histological review by senior pathologist. Primary tumors were histologically classified according to World Health Organization (35) in tubular, intestinal, signet-cell and mucinous carcinomas. Lauren and Ming $(36,37)$ classifications were also applied to primary tumors, stratifying lesions into diffuse or intestinal or infiltrating or expansive types, respectively, the latter derived from evaluation of the deepest tumor edge. Lymphatic, vascular or perineural invasion was assessed as non-detected or present. Pathological nodal status (pN) was determined histologically by counting the affected lymph nodes and classified as pN0, pN1, pN2 or pN3 according to AJCC TNM Staging system (38). Information on the tumor size as well its main location, classified as proximal or distal tumors, were obtained from original surgical pathology reports. Peri/intratumoral inflammatory infiltrate was semi-quantified as absent, mild/moderate and intense whereas desmoplasmatic stromal response as absent to mild or moderate to intense. Final pathological TNM stage was also assessed.

Immunohistochemistry analysis for RKIP. Tissue microarray (TMA) slides with $3 \mu$ m-thick sections were subjected to immunohistochemical analysis according to the streptavidinbiotin peroxidase complex system (UltraVision Large Volume Detection System Anti-Polyvalent, HRP; LabVision Corporation, CA, USA), as previously described $(27,30,39)$. Briefly, deparaffinised and rehydrated slides were submitted to heat-induced antigen retrieval for $20 \mathrm{~min}$ at $98^{\circ} \mathrm{C}$ with $10 \mathrm{mM}$ citrate buffer ( $\mathrm{pH}$ 6.0). After incubation with the primary antibody raised against RKIP (dilution 1:800; incubation $2 \mathrm{~h}$ at RT; Upstate Biotechnology, Lake Placid, NY, USA), the secondary biotinylated goat anti-polyvalent antibody was applied for $10 \mathrm{~min}$ followed by incubation with the streptavidin-peroxidase complex. The immune reaction was visualized by 3,3'-diamonobenzidine (DAB) as a chromogen. All sections were counterstained with Gill-2 haematoxylin. For negative controls, primary antibodies were omitted and also replaced by a universal negative control antibody (CEA, rabbit anti-human, Dako Corporation, Carpinteria, CA, USA). Prostate carcinoma and GISTs cases, previously analysed $(27,30,39)$, were used as positive and negative controls. Sections were independently scored by two of the authors (K.S. and A.L.F.), following a semi-quantitative criterion: $(-), 0 \%$ of immunoreactive cells; $(+),<5 \%$ of immunoreactive cells; $(++), 5-50 \%$ of immunoreactive cells; and $(+++),>50 \%$ of immunoreactive cells. Samples with scores (-) and (+) were considered negative, and those with scores $(++)$ and $(+++)$ were considered positive.

Statistical analysis. Either the $\chi^{2}$ test or Fisher's exact test (when required) was done to determine the correlation between 


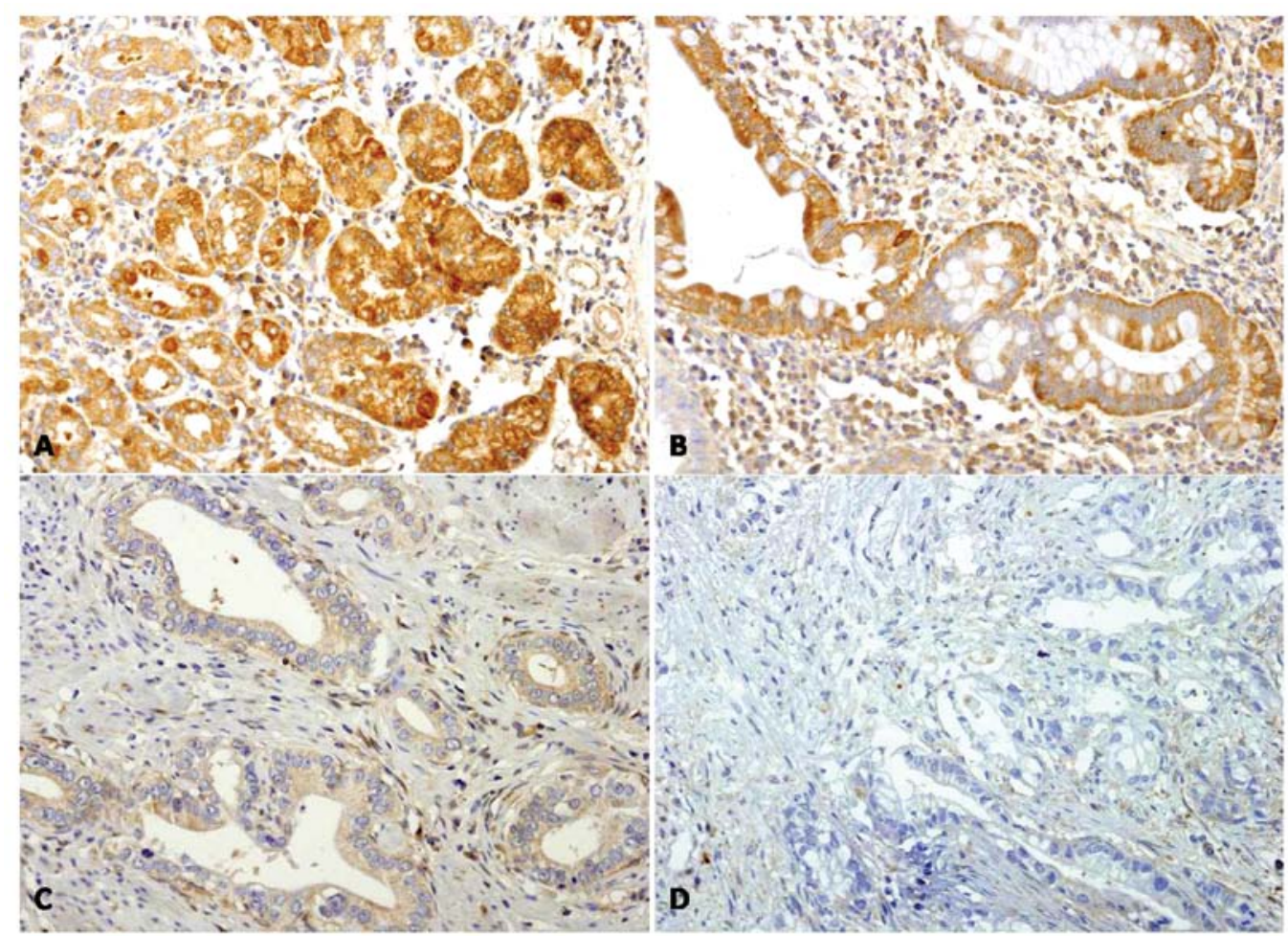

Figure 1. Immunohistochemistry analysis of RKIP in gastric samples. (A) Strong expression in normal gastric mucosa (x200). (B) Strong expression in gastric metaplasia tissue (x200). (C) Weak expression in gastric primary carcinoma (x200). (D) Negative expression in gastric lymph node metastasis tissue (x200).

RKIP expression status and clinicopathologic features. Survival curves were estimated using the Kaplan-Meier product-limit method, and the significance of the differences between survival curves was determined using a log-rank test. Multivariate survival analyses were done using the Cox proportional hazards model. Results were considered to be statistically significant for $\mathrm{p}<0.05$. All statistical analyses were conducted using SPSS 16.0 statistical software program.

\section{Results}

Patient data. We have available tissue in 152 patients, 114 with advanced and 38 early gastric cancer. The mean age was 60.89 (range: 26-87 years). The majority of patients had tumors located at the distal part of the stomach. The mean tumor size was 3.92 (range: $0.8-20 \mathrm{~cm}$ ). There was a predominance of the Lauren intestinal type. All patients were submitted to D2 lymphadenectomy with a mean number of retrieved lymph nodes of 43.7 (range: $25-113$ ). The mean follow-up was 62.3 months (range: 6-76 months), and $13.4 \%$ was lost to follow-up.

RKIP expression in gastric tissues. Four hundred and sixteen gastric tissue samples were studied for RKIP expression by immunohistochemistry. RKIP staining was always present in the cytoplasm of the cells and, according to the immunohistochemistry score, we found RKIP-positive expression in $84.7 \%$ (138/163) of normal gastric tissue, in $79.7 \%$ (47/59) of gastric mucosa metaplasia, in $44.1 \%(67 / 152)$ of gastric primary tumors, and in 9.5\% (4/42) of gastric lymph node metastasis (Table I and Fig. 1). There are no statistically significant differences between RKIP expression in normal and metapla-

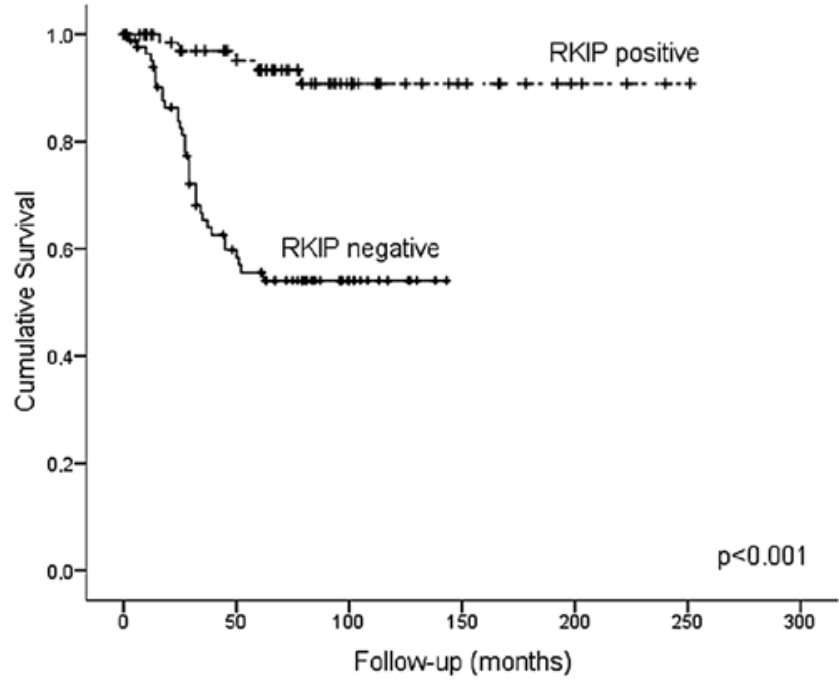

Figure 2. Overall survival according to RKIP expression in gastric carcinomas $(n=126)$. Cumulative survival is significantly lower in cases with RKIP absence of expression $(\mathrm{p}<0.001)$.

sias $(p=0.377)$. However, a statistically significant $(p<0.001)$ decrease of RKIP expression was found in primary tumors, compared to normal and metaplasia tissues, and in lymph-node metastasis, when compared to normal, metaplasia and primary tumors (Table I). Additionally, in 35 patients we had normal, tumor and metastatic tissues available. We found that RKIP was positive in non-neoplastic tissues in $\sim 83 \%$ of the patients, but was absent $\sim 69 \%$ of the primary tumors and completely absent in metastatic tissues (data not shown). 
Table II. Associations between RKIP expression and clinicopathologic features in gastric cancer patients.

\begin{tabular}{|c|c|c|c|c|}
\hline \multirow[b]{2}{*}{ Parameter } & \multirow[b]{2}{*}{$\mathrm{N}$} & \multicolumn{2}{|c|}{ RKIP expression } & \multirow[b]{2}{*}{$\mathrm{p}$} \\
\hline & & Negative (\%) & Positive (\%) & \\
\hline \multicolumn{5}{|l|}{ Gender } \\
\hline Female & 48 & $27(56.2)$ & $21(43.8)$ & 0.917 \\
\hline Male & 103 & $57(55.3)$ & $46(44.7)$ & \\
\hline \multicolumn{5}{|l|}{ Depth of invasion } \\
\hline Early & 38 & $6(15.8)$ & $32(84.2)$ & $<0.001$ \\
\hline Advanced & 114 & $79(69.3)$ & $35(30.7)$ & \\
\hline \multicolumn{5}{|l|}{ Age (years) } \\
\hline$<61$ & 68 & $33(48.5)$ & $35(61.4)$ & 0.112 \\
\hline$\geq 61$ & 83 & $51(51.5)$ & $32(38.6)$ & \\
\hline \multicolumn{5}{|l|}{ Tumor size (cm) } \\
\hline$<4$ & 52 & $19(36.5)$ & $33(63.5)$ & $<0.001$ \\
\hline$\geq 4$ & 98 & $65(66.3)$ & $33(33.7)$ & \\
\hline \multicolumn{5}{|l|}{ Tumor location } \\
\hline Proximal & 16 & $9(56.2)$ & $7(43.8)$ & 0.974 \\
\hline Distal & 129 & $72(55.8)$ & $57(44.2)$ & \\
\hline \multicolumn{5}{|l|}{ WHO classification } \\
\hline Intestinal adenocarcinoma & 14 & $1(7.1)$ & $13(92.9)$ & 0.030 \\
\hline Tubular adenocarcinoma & 66 & $46(69.7)$ & $20(30.3)$ & \\
\hline Mucinous adenocarcinoma & 14 & $9(64.3)$ & $5(35.7)$ & \\
\hline Signet-ring cell carcinoma & 36 & $23(63.9)$ & $13(36.1)$ & \\
\hline \multicolumn{5}{|l|}{ pT } \\
\hline Muscular propria/subserosa & 111 & $76(68.5)$ & $35(31.5)$ & $<0.001$ \\
\hline Submucosa & 38 & $6(15.8)$ & $32(84.2)$ & \\
\hline \multicolumn{5}{|l|}{ Lauren } \\
\hline Intestinal & 99 & $55(55.6)$ & $44(44.4)$ & 0.855 \\
\hline Diffuse & 49 & $28(57.1)$ & $21(42.9)$ & \\
\hline \multicolumn{5}{|l|}{ Lymphatic Invasion } \\
\hline Absent & 84 & $39(46.4)$ & $45(53.6)$ & 0.009 \\
\hline Present & 68 & $46(67.6)$ & $22(32.4)$ & \\
\hline \multicolumn{5}{|l|}{ Vascular Invasion } \\
\hline Absent & 131 & $69(52.7)$ & $62(47.3)$ & 0.044 \\
\hline Present & 21 & $16(76.2)$ & $5(23.8)$ & \\
\hline \multicolumn{5}{|l|}{ Perineural invasion } \\
\hline Absent & 86 & $40(46.5)$ & $46(53.5)$ & 0.008 \\
\hline Present & 66 & $45(67.2)$ & $21(31.8)$ & \\
\hline \multicolumn{5}{|l|}{ Inflammatory infiltrated } \\
\hline Absent/mild & 118 & $62(52.5)$ & $56(47.5)$ & 0.233 \\
\hline Moderated/accentuated & 31 & $20(64.5)$ & $11(35.5)$ & \\
\hline \multicolumn{5}{|l|}{ Desmoplasia } \\
\hline Absent/discrete & 84 & $42(50.0)$ & $42(50.0)$ & 0.081 \\
\hline Moderated/accentuated & 67 & $43(64.2)$ & $24(35.8)$ & \\
\hline \multicolumn{5}{|l|}{ TNM } \\
\hline IA & 37 & $6(16.2)$ & $31(83.8)$ & $<0.001$ \\
\hline IB & 34 & $24(70.6)$ & $10(29.4)$ & \\
\hline II & 52 & $34(65.4)$ & $18(34.6)$ & \\
\hline IIIA+IV & 27 & $20(74.1)$ & $7(25.9)$ & \\
\hline \multicolumn{5}{|l|}{ Lymph node metastasis } \\
\hline $\mathrm{pNO}$ & 72 & $29(40.3)$ & $43(59.7)$ & 0.004 \\
\hline $\mathrm{pN} 1$ & 55 & $37(67.3)$ & $18(32.7)$ & \\
\hline $\mathrm{pN} 2$ & 23 & $17(73.9)$ & $6(26.1)$ & \\
\hline
\end{tabular}

$\mathrm{N}$, number of cases; $\mathrm{cm}$, centimeters; $\mathrm{SD}$, standard deviation. 
Table III. Correlations between clinicopathologic features and overall survival in gastric cancer patients.

\begin{tabular}{|c|c|c|c|c|c|}
\hline \multirow[b]{2}{*}{ Parameter } & \multirow[b]{2}{*}{$\mathrm{N}$} & \multicolumn{2}{|c|}{ Univariate analysis } & \multicolumn{2}{|c|}{ Multivariate analysis } \\
\hline & & (months $\pm \mathrm{SD}$ ) & $\mathrm{p}^{\mathrm{a}}$ & Hazard ratio $(95 \% \mathrm{CI})$ & $\mathrm{p}^{\mathrm{b}}$ \\
\hline \multicolumn{6}{|l|}{ Gender } \\
\hline Female & 40 & $211.6 \pm 13.5$ & 0.018 & 1.00 & \\
\hline Male & 85 & $145.6 \pm 10.6$ & & $2.95(1.25-6.98)$ & 0.014 \\
\hline \multicolumn{6}{|l|}{ Tumor size (cm) } \\
\hline$<4$ & 74 & $203.1 \pm 10.9$ & 0.002 & 1.00 & \\
\hline$\geq 4$ & 50 & $100.7 \pm 10.1$ & & $2.35(0.88-6.24)$ & 0.086 \\
\hline \multicolumn{6}{|l|}{ WHO classification } \\
\hline Intestinal adenocarcinoma & 11 & $173.3 \pm 17.3$ & 0.008 & & \\
\hline Tubular adenocarcinoma & 59 & $125.9 \pm 8.4$ & & & \\
\hline Mucinous adenocarcinoma & 11 & $84.2 \pm 15.3$ & & & \\
\hline Signet-ring cell carcinoma & 24 & $55.54 \pm 7.3$ & & & \\
\hline \multicolumn{6}{|l|}{ Lauren } \\
\hline Intestinal & 81 & $193.3 \pm 11.1$ & 0.019 & 1.00 & \\
\hline Diffuse & 39 & $139.5 \pm 17.2$ & & $1.56(0.74-3.28)$ & 0.244 \\
\hline \multicolumn{6}{|l|}{ Lymph node metastasis } \\
\hline pNO & 59 & $231.4 \pm 8.3$ & $<0.001$ & 1.00 & \\
\hline $\mathrm{pN} 1$ & 47 & $106.2 \pm 10.3$ & & $4.05(1.45-11.27)$ & 0.007 \\
\hline $\mathrm{pN} 2$ & 15 & $48.1 \pm 10.6$ & & $6.63(2.08-21.14)$ & 0.001 \\
\hline \multicolumn{6}{|l|}{ Lymphatic invasion } \\
\hline Absent & 70 & $206.9 \pm 10.9$ & 0.002 & & \\
\hline Present & 50 & $103.0 \pm 9.9$ & & & \\
\hline \multicolumn{6}{|l|}{ Vascular invasion } \\
\hline Absent & 105 & $189.1 \pm 9.9$ & 0.009 & 1.00 & \\
\hline Present & 14 & $85.8 \pm 18.9$ & & $1.01(0.49-2.10)$ & 0.974 \\
\hline \multicolumn{6}{|l|}{ Perineural invasion } \\
\hline Absent & 68 & $222.7 \pm 9.3$ & $<0.001$ & 1.00 & \\
\hline Present & 52 & $82.8 \pm 7.9$ & & $1.26(0.52-3.06)$ & 0.605 \\
\hline \multicolumn{6}{|l|}{ RKIP expression } \\
\hline Positive & 58 & $230.2 \pm 8.8$ & & 1.00 & \\
\hline Negative & 68 & $84.5 \pm 7.1$ & $<0.001$ & $4.53(1.52-13.53)$ & 0.007 \\
\hline
\end{tabular}

${ }^{a}$ Log-rank test; ${ }^{b}$ multivariate Cox proportional of Hazards model; SD, standard deviation; CI, confidence interval.

RKIP expression and correlation with clinical data. The correlations between RKIP expression and clinicopathologic features are summarized in Table II. We found that RKIP is differently expressed between the different WHO histological types $(\mathrm{p}=0.03)$, being highly expressed in intestinal type, and lost in tubular, mucinous and signet-ring cell carcinomas. At variance, no statistically differences were observed among the Lauren subtypes. RKIP is significantly lost in advanced gastric cancer when compared with early tumors $(\mathrm{p}<0.001)$. Additionally, absence of RKIP expression was statistically associated with tumors with higher tumor size, with higher TNM stage, with the presence of vascular, lymphatic and neuronal invasion and with the presence of lymph node metastasis (Table II).

Correlations with patients survival. We found that additionally to the above mentioned clinical factors, the absence of RKIP expression is also significantly $(\mathrm{p}<0.001)$ associated with poor overall survival in gastric carcinoma patients (Table III and Fig. 2). To evaluate whether RKIP expression is an independent prognostic factor, we carried out a multivariate Cox regression analysis and found that absence of RKIP expression is independently associated with patients poor survival with a 4.53 hazard ratio (Table III). Additionally, male gender, higher tumor size and presence of lymph node metastasis were also found to be independent prognostic factors in our series of gastric carcinomas (Table III).

\section{Discussion}

Gastric carcinoma is still the fourth most common cancer and the second leading cause of cancer-related death in the world (1). Although excellent long-term survival results for early- 
detected gastric cancer exist, prognosis of advanced gastric cancer still remains poor (40). Prognosis of gastric carcinoma patients depends on several pathological and genetic variables, such as TNM grading and p53, MUC1, and E-cadherin (41-44). However, patient outcome is difficult to predict using classic histological and molecular classifications. Therefore, additional markers are required to identify patients with risk to metastasize and with poor prognosis.

Initial in vitro studies, showed that cell lines derived from metastatic prostate cancer displayed decreased levels of RKIP as compared with primary tumor cell lines, leading to the suggestion of RKIP as a metastasis suppressor (18). Subsequent studies showed that overexpression of RKIP in prostate and melanoma cell lines suppresses metastasis by decreasing vascular invasion $(18,20)$. Previous studies have described low levels of RKIP in other metastatic tumors, such as breast and colorectal carcinoma $(23,45)$, as well as in many other primary tumors, including GISTs (27), insulinoma (22), hepatocarcinoma (24), ovarian carcinoma (26), merckel cell carcinoma (16) and thyroid carcinoma (15), cutaneous squamous cell carcinoma (46) and nasopharyngeal carcinoma (17). Furthermore, loss of cytoplasmic RKIP has also been associated with poor prognosis in prostate, colorectal, GISTs and glial tumors (25,27-30).

In gastric tumors, previous studies concerning RKIP expression are contradictory. Chatterjee and collaborators reported that in non-neoplastic gastric tissue RKIP cytoplasmic staining was predominantly negative, and in tumor tissues only $29 \%(42 / 143)$ of cases stained positive (31). In contrast, Wang and collaborators described that RKIP is present in $\sim 88 \%$ (35/40) of non-neoplastic tissues, in 52\% (39/75) of the primary tumors and only in $19 \%$ (5/26) of lymph node metastasis (32). More recently, RKIP was shown to be present in 38\% (21/55) of gastric cancer tumor tissues (33). In the present study, we showed that RKIP is highly expressed in $~ 83 \%$ (185/222) of non-neoplastic tissues (normal and metaplastic gastric mucosa), but is significantly lost in 55\% (93/168) of primary tumors and almost absent in gastric lymph node metastasis with only $\sim 10 \%$ (4/42) of the sample staining positive, being in accordance to that described by Wang et al (32) in a smaller series. Our results suggested that RKIP could have an important role in normal gastric mucosa and downregulation to gastric cancer progression and metastatic mechanisms. To support this hypothesis, we also found that absence of RKIP protein is statistically associated with the presence of lymph node metastasis, which fits well with described for gastric and other epithelial tumors $(18,23,33,45)$. Additionally, the absence of RKIP expression is significantly associated with clinical features that were associated with poor prognosis in these patients (i.e., advanced tumors, higher tumor size, WHO classification, muscular propria/subserosa invasion, higher TNM stage, and lymphatic, neural and vascular invasion). Significantly, we found that RKIP negativity is an independent prognostic marker of worse prognosis in gastric cancer patients. Despite the reported absence of RKIP expression in non-neoplastic gastric tissue, Chatterjee et al also found that the absence of RKIP expression was associated with poor prognosis, but only in intestinal type of gastric cancer (31).

Despite the importance of RKIP as a metastasis and prognostic marker in human cancer, the mechanisms of RKIP downregulation remains to be unraveled (12). Some studies have investigated the methylation status of RKIP promoter in colorectal cancer as a possible mechanism, however, the results are discrepant $(12,45,47)$. In GISTs loss of RKIP expression was not associated with gene promoter methylation (27). Of note, in GISTs, the absence of RKIP was predominant (4 out of 6 ) in tumors with a gastric location (27). Further studies are needed to evaluate the possible mechanisms of RKIP downregulation in gastric cancer.

Due to the pivot role of RKIP in tumor progression and in metastasis, its re-activation can constitute an attractive therapeutic strategy. In non-Hodgkin's lymphoma cell lines it was shown that treatment with Rituximab induced RKIP upregulation, with further sensitization to chemotherapeutic induced apoptosis (48). Other studies reported that RKIP can be induced by nitric oxide or the proteasome inhibitor NPI-0052, via NF- $\kappa$ B inhibition (49-51).

We herein reported the frequency of RKIP expression in a large and clinically well-characterized series of different gastric tissue samples. We showed that RKIP expression is lost during gastric tumor progression, been practically absent in lymph node metastasis. Importantly, we observed that the RKIP loss is associated with other clinical characteristic of tumor aggressiveness and constitutes an independent biomarker of poor prognosis in gastric cancer patients.

\section{Acknowledgements}

Olga Martinho was recipient of a $\mathrm{PhD}$ fellowship (SFRH/ BD/36463/2007) from Fundação para a Ciência e Tecnologia (FCT), Portugal.

\section{References}

1. Crew KD and Neugut AI: Epidemiology of gastric cancer. World J Gastroenterol 12: 354-362, 2006.

2. Dicken BJ, Bigam DL, Cass C, Mackey JR, Joy AA and Hamilton SM: Gastric adenocarcinoma - Review and considerations for future directions. Ann Surg 241: 27-39, 2005.

3. Vauhkonen M, Vauhkonen $\mathrm{H}$ and Sipponen P: Pathology and molecular biology of gastric cancer. Best Pract Res Clin Gastroenterol 20: 651-674, 2006.

4. Milne AN, Carneiro F, O'Morain C and Offerhaus GJ: Nature meets nurture: molecular genetics of gastric cancer. Hum Genet 126: 615-628, 2009.

5. Bernier I and Jolles P: Purification and characterization of a basic $23 \mathrm{kDa}$ cytosolic protein from bovine brain. Biochim Biophys Acta 790: 174-181, 1984.

6. Hori N, Chae KS, Murakawa K, Matoba R, Fukushima A, Okubo K, et al: A human cDNA sequence homologue of bovine phosphatidylethanolamine-binding protein. Gene 140: 293-294, 1994.

7. Seddiqi N, Bollengier F, Alliel PM, Périn JP, Bonnet F, Bucquoy S, et al: Amino acid sequence of the Homo sapiens brain 21-23-kDa protein (neuropolypeptide h3), comparison with its counterparts from Rattus norvegicus and Bos taurus species, and expression of its mRNA in different tissues. J Mol Evol 39: 655-660, 1994.

8. Yeung K, Seitz T, Li S, Janosch P, McFerran B, Kaiser C, et al: Suppression of Raf-1 kinase activity and MAP kinase signalling by RKIP. Nature 401: 173-177, 1999

9. Yeung K, Janosch P, McFerran B, Rose DW, Mischak H, Sedivy JM, et al: Mechanism of suppression of the Raf/MEK/ extracellular signal-regulated kinase pathway by the raf kinase inhibitor protein. Mol Cell Biol 20: 3079-3085, 2000.

10. Yeung KC, Rose DW, Dhillon AS, Yaros D, Gustafsson M, Chatterjee $\mathrm{D}$, et al: Raf kinase inhibitor protein interacts with NF-kappaB-inducing kinase and TAK1 and inhibits NF-kappaB activation. Mol Cell Biol 21: 7207-7217, 2001 
11. Lorenz K, Lohse MJ and Quitterer U: Protein kinase C switches the Raf kinase inhibitor from Raf-1 to GRK-2. Nature 426: 574-579, 2003

12. Al-Mulla F, Hagan S, Al-Ali W, Jacob SP, Behbehani AI, Bitar MS, et al: Raf kinase inhibitor protein: mechanism of loss of expression and association with genomic instability. J Clin Pathol 61: 524-529, 2008.

13. Klysik J, Theroux SJ, Sedivy JM, Moffit JS and Boekelheide K: Signaling crossroads: The function of Raf kinase inhibitory protein in cancer, the central nervous system and reproduction. Cell Signal 20: 1-9, 2008.

14. Granovsky AE and Rosner MR: Raf kinase inhibitory protein: a signal transduction modulator and metastasis suppressor. Cell Res 18: 452-457, 2008.

15. Akaishi J, Onda M, Asaka S, Okamoto J, Miyamoto S, Nagahama M, et al: Growth-suppressive function of phosphatidylethanolamine-binding protein in anaplastic thyroid cancer. Anticancer Res 26: 4437-4442, 2006.

16. Houben R, Michel B, Vetter-Kauczok CS, Pföhler C, Laetsch B, Wolter MD, et al: Absence of classical MAP kinase pathway signalling in Merkel cell carcinoma. J Invest Dermatol 126 1135-1142, 2006.

17. Chen Y, Ouyang GL, Yi H, Li MY, Zhang PF, Li C, et al: Identification of RKIP as an Invasion Suppressor Protein in nasopharyngeal carcinoma by proteomic analysis. J Proteome Res 7: 5254-62, 2008.

18. Fu Z, Smith PC, Zhang L, Rubin MA, Dunn RL, Yao Z, et al: Effects of raf kinase inhibitor protein expression on suppression of prostate cancer metastasis. J Natl Cancer Inst 95: 878-889, 2003.

19. Chatterjee D, Bai Y, Wang Z, Beach S, Mott S, Roy R, et al: RKIP sensitizes prostate and breast cancer cells to drug-induced apoptosis. J Biol Chem 279: 17515-17523, 2004.

20. Schuierer MM, Bataille F, Hagan S, Kolch W and Bosserhoff AK Reduction in Raf kinase inhibitor protein expression is associated with increased Ras-extracellular signal-regulated kinase signaling in melanoma cell lines. Cancer Res 64: 5186-5192, 2004.

21. Schuierer MM, Bataille F, Weiss TS, Hellerbrand C and Bosserhoff AK: Raf kinase inhibitor protein is downregulated in hepatocellular carcinoma. Oncol Rep 16: 451-456, 2006.

22. Zhang L, Fu Z, Binkley C, Giordano T, Burant CF, Logsdon CD, et al: Raf kinase inhibitory protein inhibits beta-cell proliferation. Surgery 136: 708-715, 2004.

23. Hagan S, Al-Mulla F, Mallon E, Oien K, Ferrier R, Gusterson B, et al: Reduction of Raf-1 kinase inhibitor protein expression correlates with breast cancer metastasis. Clin Cancer Res 11: 7392-7397, 2005

24. Lee HC, Tian B, Sedivy JM, Wands JR and Kim M: Loss of Raf kinase inhibitor protein promotes cell proliferation and migration of human hepatoma cells. Gastroenterology 131: $1208-1217,2006$.

25. Al-Mulla F, Hagan S, Behbehani AI, Bitar MS, George SS, Going JJ, et al: Raf kinase inhibitor protein expression in a survival analysis of colorectal cancer patients. J Clin Oncol 24 5672-5679, 2006.

26. Li HZ, Wang Y, Gao Y, Shao J, Zhao XL, Deng WM, et al: Effects of raf kinase inhibitor protein expression on metastasis and progression of human epithelial ovarian cancer. Mol Cancer Res 6: 917-928, 2008

27. Martinho O, Gouveia A, Silva P, Pimenta A, Reis RM and Lopes JM: Loss of RKIP expression is associated with poor survival in GISTs. Virchows Arch 455: 277-284, 2009.

28. Fu Z, Kitagawa Y, Shen R, Shah R, Mehra R, Rhodes D, et al: Metastasis suppressor gene Raf kinase inhibitor protein (RKIP) is a novel prognostic marker in prostate cancer. Prostate 66: 248-256, 2006

29. Zlobec I, Baker K, Minoo P, Jass JR, Terracciano L and Lugli A: Node-negative colorectal cancer at high risk of distant metastasis identified by combined analysis of lymph node status, vascular invasion, and Raf-1 kinase inhibitor protein expression. Clin Cancer Res 14: 143-148, 2008.

30. Martinho O, Granja S, Jaraquemada T, Caeiro C, MirandaGonçalves V, Honavar M, et al: Downregulation of RKIP is associated with poor outcome and malignant progression in gliomas. PLoS One 7: e30769, 2012.
31. Chatterjee D, Sabo E, Tavares R and Resnick MB: Inverse association between Raf Kinase Inhibitory Protein and signal transducers and activators of transcription 3 expression in gastric adenocarcinoma patients: implications for clinical outcome. Clin Cancer Res 14: 2994-3001, 2008.

32. Wang J, Yang YH, Wang AQ, Yao B, Xie G, Feng G, et al: Immunohistochemical detection of the Raf kinase inhibitor protein in nonneoplastic gastric tissue and gastric cancer tissue. Med Oncol 27: 219-23, 2010

33. Jia B, Liu H, Kong Q and Li B: RKIP expression associated with gastric cancer cell invasion and metastasis. Tumour Biol 33: 919-925, 2012.

34. Pinheiro C, Longatto-Filho A, Simões K, Jacob CE, Bresciani CJ, Zilberstein B, et al: The prognostic value of CD147/EMMPRIN is associated with monocarboxylate transporter 1 co-expression in gastric cancer. Eur J Cancer 45: 2418-2424, 2009.

35. Fenoglio-Preiser C, Carneiro F, Powell SM, et al: Tumors of the stomach. In: Pathology and Genetics of Tumors of the Digestive System. Hamilton LAA (ed). Lyon, IARC Press, pp37-66, 2000.

36. Lauren T: The two histologic main types of gastric carcinoma Acta Pathol Microbiol Scand 64: 34, 1962.

37. Ming SC: Gastric carcinoma. A pathobiological classification. Cancer 39: 2475-85, 1977

38. Greene FL, Page DL, Fleming ID, et al: AJCC Cancer Staging Manual, 6th edition. Springer, New York, 2002.

39. Martinho O,Faloppa CC,Scapulatempo Neto C,Longatto-Filho A, Baiocchi G, Werneck da Cunha I, et al: Loss of RKIP expression during the carcinogenic evolution of endometrial cancer. J Clin Pathol 65: 122-8, 2012.

40. Desai AM, Pareek M, Nightingale PG and Fielding JW: Improving outcomes in gastric cancer over 20 years. Gastric Cancer 7: 196-203, 2004.

41. Gabbert HE, Muller W, Schneiders A, Meier S and Hommel G: The relationship of $\mathrm{p} 53$ expression to the prognosis of 418 patients with gastric carcinoma. Cancer 76: 720-726, 1995.

42. Utsunomiya T, Yonezawa S, Sakamoto H, Kitamura H, Hokita S, Aiko T, et al: Expression of MUC1 and MUC2 mucins in gastric carcinomas: its relationship with the prognosis of the patients. Clin Cancer Res 4: 2605-2614, 1998

43. Yonemura Y, Nojima N, Kaji M, Fujimura T, Itoh H, Ninomiya I, et al: E-cadherin and urokinase-type plasminogen activator tissue status in gastric carcinoma. Cancer 76: 941-953, 1995.

44. Washington K, Gottfried MR and Telen MJ: Expression of the cell adhesion molecule CD44 in gastric adenocarcinomas. Hum Pathol 25: 1043-1049, 1994

45. Minoo P, Zlobec I, Baker K, Tornillo L, Terracciano L, Jass JR, et al: Loss of Raf-1 kinase inhibitor protein expression is associated with tumor progression and metastasis in colorectal cancer. Am J Clin Pathol 127: 820-827, 2007.

46. Zaravinos A, Kanellou P, Baritaki S, Bonavida B and Spandidos DA: BRAF and RKIP are significantly decreased in cutaneous squamous cell carcinoma. Cell Cycle 8: 1402-1408, 2009.

47. Minoo P, Baker K, Goswami R, Chong G, Foulkes WD, Ruszkiewicz AR, et al: Extensive DNA methylation in normal colorectal mucosa in hyperplastic polyposis. Gut 55: 1467-74, 2006

48. Jazirehi AR, Vega MI, Chatterjee D, Goodglick L and Bonavida B: Inhibition of the Raf-MEK1/2-ERK1/2 signaling pathway, Bcl-xL down-regulation, and chemosensitization of non-Hodgkin's lymphoma B cells by Rituximab. Cancer Res 64: 7117-7126, 2004.

49. Bonavida B, Baritaki S, Huerta-Yepez S, Vega MI, Chatterjee D and Yeung K: Novel therapeutic applications of nitric oxide donors in cancer: roles in chemo- and immunosensitization to apoptosis and inhibition of metastases. Nitric Oxide 19: 152-157, 2008.

50. Baritaki S, Yeung K, Palladino M, Berenson J and Bonavida B: Pivotal roles of snail inhibition and RKIP induction by the proteasome inhibitor NPI-0052 in tumor cell chemoimmunosensitization. Cancer Res 69: 8376-8385, 2009.

51. Baritaki S, Chapman A, Yeung K, Spandidos DA, Palladino M and Bonavida B: Inhibition of epithelial to mesenchymal transition in metastatic prostate cancer cells by the novel proteasome inhibitor, NPI-0052: pivotal roles of Snail repression and RKIP induction. Oncogene 28: 3573-3585, 2009. 